\title{
Gender and internet use pattern of pre-service teachers in Nigerian College of Education
}

\author{
Elizabeth Morenikeji Titilayo Adediran, Albert Oluyomi Kehinde \\ Department of Curriculum Studies And Educational Technology (CUSET), \\ Federal College of Education, Abeokuta, Ogun State, Nigeria
}

\begin{abstract}
The gender gap is a critical challenge that threatens to leave millions of women and girls behind in an increasingly globally connected world. This study sets out to investigate Internet Use Patterns among Student Teachers in a Nigeria College of Education with a view to determine the type of use made of the Internet by the student teachers and investigate the effect of gender on the use of the Internet by the student teachers. The questionnaire known as Internet Use questionnaire was administered to final year students of Federal College of Education, Abeokuta. The results indicate that getting information for school work, communication, chatting and social networking are the major use to which the participants put the internet. It also indicates that gender affects both use and feeling of pre-service teachers about the internet. This implies that gender is a major factor to be considered in use of as well as feeling about the internet.
\end{abstract}

Keywords: internet use; gender; pre-service teachers; colleges of education; technology use

\section{INTRODUCTION}

The Internet is a global system of connections between millions of computers that allows almost instant access to and dissemination of information. Nowadays internet has become so common due to the speedy development of technology and globalization. Societies are becoming more and more unified. Sharing of information through the internet has made it to become a reliable tool. The use of the Internet as an instructional tool in higher education is rapidly increasing. Today, there is an increase in the development of academic course websites with huge amounts of learning materials imbedded within them. The Internet's ability to provide students quick access to information sources and databases located at geographicallyremoved institutions makes it a valuable information source for students (Benson, 1994; Browne et al., 2000; Lubans, 1998; Ryan, 1994).

There is no gainsaying that the internet is useful for educational purposes. It is widely used to gather information so as to do research or add to the knowledge of any sort of subject they have. The integration of the Internet as a teaching tool in academic courses has grown rapidly. Many universities, including leading academic institutes, are implementing advanced technologies as a part of existing teaching frameworks (AFT, 2001; Bonk, 2001). As noted by Ruzgar (2005), new technologies are rapidly changing our ways of communication, and also the art of teaching, as well as extending ways of learning. The dramatic growth of Internet usage 
has changed the lives of millions of people around the globe during the last decade. For students and teachers, the Internet is becoming an increasingly important part of the educational process.

Usun (2003) asserted that the Internet can be used to complement a lecture where the instructor asks students to find specified Web sites to gain more in-depth knowledge about a particular topic. It may also be used to replace the traditional classroom lecture where courses are offered via the Internet. The instructor may place course notes on Web pages or may create a video recording of a live lecture for viewing on the Internet, or use combinations of these ideas. Serim (2010) further asserted that students today have brought the Internet into their classrooms, and learning will never again be limited to the confines of a classroom's four walls. Among the ten reasons adduced for this by Serim (2010) are provision of free (or low cost) materials to the teachers, with the click of the mouse students routinely take virtual field trips to every corner of the earth, motivation of students and allowing students to learn by doing.

The teacher remains an important factor in instruction delivery. He is the one to plan the lesson, manage time materials and the students in the class as he delivers his instruction. University of Northern Colorado (2013) citing Evertson, Emmer and Worsham (2006) in corroboration of (Marzano, Pickering, \& Pollock, 2001) asserted that the functions of an effective teacher include wise selection of the most effective instruction strategies to employ, designing classroom curriculum to facilitate student learning as well as making effective use of classroom management techniques. Thus, the more the skill or expertise of the teacher in selection and use of appropriate strategy in instructional delivery together with effective management of the class, the more effective such instruction would be. It is believed that preservice teachers are in training to acquire needed skills that will make them function effectively in their chosen career when they eventually get to the field. More specifically, pre-service teachers who are still in training are expected to have good knowledge and skill in internet use. This is because instruction today is mainly technology driven. This corroborates Ruzgar (2005), who noted that new technologies are rapidly changing our ways of communication, and also the art of teaching, as well as extending ways of learning.

Gender is an enduring characteristic of students that stands as an important variable which could produce differences in individuals. Gender is intertwined with identity, expression, presentation, relationships and societal role and structure, among other things. As noted by the United Nations (2008) gender refers to the social attributes and opportunities associated with being male and female and the relationships between women and men and girls and boys, as well as the relations between women and those between men. Gender determines what is expected, allowed and valued in a women or a man in a given context. In most societies there are differences and inequalities between women and men in responsibilities assigned, activities undertaken, access to and control over resources, as well as decision-making opportunities.

Gender has been found to produce differences in human beings. Gender is one of the universal dimensions on which differences are based. This is because men and women are also "specialized" for different tasks (Dholakia, Dholakia \& Kshetri, 2003). While asserting that scientific research frequently concludes that men and women excel in different areas, Viegas (2013) recently identified some gender differences backed up by science. These include the facts that men have better judgment of a person's size based on their voice just as they have better spatial awareness. More so, men handle lack of sleep better than women do.

On the other hand, women are better at locating specific items, are better at worrying, just as they detect colors better than men do. However, both males and females have been found to be evenly matched at multitasking and in terms of intelligence. 


\section{Statement of the problem}

It is believed that post-secondary students are heavier users of the Internet than the general population (Nie, Simpser, Stepanikova, \& Zheng, 2005; UCLA World Internet Project, 2004). Even at the secondary school level, students now bring internet to class. It is therefore imperative that teachers in training should have the skill and be prepared to use the internet. Otherwise, the tendency is for them not to be adequately informed and prepared for the job they are training for. However, due to difference in gender, there is the tendency to be a difference in the way both males and females acquire and use these skills which will also produce a consequential difference in their readiness to use it on the field.

\section{Objectives of the study}

It is against this background that this study sets out to investigate Internet Use Patterns among Student Teachers in a Nigeria College of Education with a view to achieving the following objectives:

To determine the type of use made of the Internet by the student teachers.

To investigate the effect of gender on the use of the Internet by the student teachers

To investigate the type of feelings the male and female participants have about the internet

\section{Hypothesis}

The following null hypotheses are to be tested at .05 level of significance

There is no significant difference in the general use of the internet by male and female participants

There is no significant difference in the specific use of the internet by male and female participants

There is no significant difference in the feelings of male and female participants about the internet

\section{Literature review}

Various pattern of use of the internet have been identified in literature. Stern's (2002) study was on the information competence of incoming students into universities and how they use the Internet for general and academic research. She dwelt on the fact that information has increased at an astounding rate and that educators recognize that it is not enough to introduce students to discreet chunks of information from traditional sources such as paper-based books or journals. Lifelong learners must be equipped with skills to effectively and intelligently find, evaluate, manage, apply, create, publish and store, and retrieve information using both conventional research resources as well as digital tools, such as the Internet, that access very diverse databases of information. Tadasad, Maheswarapp, and Alur (2003) studied Internet use at PDA College of Engineering, Gulbarga. Their observation was that Internet use is confined to general or recreational purposes, and that its potential in supporting curricular requirements has not been realized by students.

Ruzgar (2005) conducted a survey at a Turkish University to obtain student views about intensity of Internet use, reasons for using the Internet, impact of the Internet on student life, via the Internet, web-based lecture notes, exercises, an electronic discussion panel and an internal course email communication system and their future plans about web-based learning. The results indicate that young generation is exposed to Internet at very early ages and this will rapidly increase Internet usage in the near future. Sending/receiving e-mail topped the list in 
sample followed by research for school-related work. Approximately fifty percent of students believe that Internet access at home improves their grade-point-averages (GPAs).

Selwyn, Marriott and Marriott's (2000) carried out a study on students' use of internet, via focus group interview with 77 students in two UK universities, and explored the factors underlying their use (and non-use) of the Internet in university. Four crucial themes were identified, namely; (1) the ways in which students were introduced to using the Internet, (2) operational problems encountered when using the Internet as an information resource, (3) treatment of information retrieved from the Internet, (4) the social element of learning in online environments. These factors were examined in detail and discussed in relation to the future presentation and organization of students' Internet use in university settings.

In relation to Nigerian context, Jagboro (2003) found that Internet was the fourth most important resources for materials .among the postgraduate students with respondents using the Internet to access research materials and for email. The study concluded that the use of Internet for academic activities would improve significantly with more access in departments and faculties. Ojokoh and Asaolu (2005) studied the internet access and usage by students of Federal University of Technology, Akure and found that only $3.4 \%$ of the respondents were not using the Internet. Cybercafés were the most frequent source of Internet access, and most of the respondents acquired Internet skills through teaching by friends.

A study by Omotayo (2006) surveyed the use of Internet among undergraduate students at the Obafemi Awolowo University, Ile-Ife, Nigeria. The findings revealed a high percentage use of the Internet. The access point for them is cyber cafes. The university library though linked to the Internet is yet to provide access to students. Respondents pay for the access time through their pocket money for food, books and assistance from friends. Their use of the Internet has not affected their use of the library. Some problems they face in their use of the Internet include slowness of the server and payment for the access time. The study recommends that the university should provide access points for students. The university library also should continue to aim at ensuring that it gets enough funds from the government and sponsors to be able to provide access points in the library for use by students and include the use of Internet in its library instruction course.

Anasi (2006) investigated the pattern of Internet use by students of the University of Lagos and found low use of Internet among students from Law and Education, though Internet use had very high impact on their academic career. Mishra (2009) studied the use of Internet at the University of Maiduguri, Nigeria. The findings showed that Internet was very important for $60.8 \%$ of the respondents, with $74.6 \%$ using the Internet for research; $71.5 \%$ mentioned Google as their preferred search engine and concludes that necessary facilities should be put in place for faculty and student to make optimal use of information resources

In relation to gender, Singh (2001) asserted that in the United States and Australia, men and women use the internet in nearly equal measure, whereas in Japan, India and China, men continue to dominate internet use. Sherman and et al. (2000) investigated the Internet gender gap among college students by comparing the usage patterns and attitudes of three cohort of students in 1997, 1998 and 1999. Attitudes toward the technology also differed between men and women and these differences also did not change over time. The longitudinal data showed similar patterns. In general, investigation suggests that differences continue to exist between collage men and women in how they experience Internet technology. It also suggest that the. assessments that the Internet will soon be gender neutral are likely to be premature. Odell, Korgen, Schumcher, and Delucchi (2000) studied Internet use among female and male college students at institutions of higher learning in Georgia, Hawaii, New Jersey, Massachusetts and Rhode Island. They found that while the gap in use of the Internet has nearly closed, there 
remain differences in how male and female undergraduates use the Internet. Ono, H. (2003) reported on a study of differences in men's and women's use of the Internet between 1997 and 2001. The results showed that though women were significantly less likely than men to use the Internet at all in 1997 and 1998, women were more likely than men to use the Internet in 2001.

Nai \& Gill (2007) investigated differences in use of, and attitudes toward the Internet and computers generally for Chinese and British students, and gender differences in this crosscultural context. The study revealed that men in both countries were more likely than women to use email or chat rooms. Men played more computer games than women and were more likely to express the opinion that using computers was a male activity and skill than were women. Women have however been found to see the internet as a tool. A study by Singh (2001) found that women generally use the internet as a tool for activities, rather than as play or a technology to be mastered. This partially explains why women farmers use the internet more extensively than their farmer husbands. When women become comfortable with technology as with the telephone or the PC on a farm - women see it as a tool rather than a technology. Women's continued discomfort with technology thus remains at the centre of the social construct of gender and technology.

Related to use is access. In this vein, Denny-Brown \& Thomas (2013) reported on a groundbreaking study on the Internet access gender gap in the developing world. The study found that more than 200 million fewer women have access to the Internet in developing countries than men. This equates to a gender gap of nearly $25 \%$, meaning that for every four men in the developing world who have access to the Internet's opportunities and benefits, only three women have that same access.

It is therefore obvious while some studies found women use the internet more, others found the contrary. More importantly, for a developing country like Nigeria, inequalities in Internet access and gender differences in Internet usage remain issues of concern

\section{METHODOLOGY}

The questionnaire known as Internet Use questionnaire was developed purposely to collect data on internet use pattern of student teachers in Colleges of Education. This likert-type questionnaire comprises five sections. Section A comprise of items on the personal data of the respondents, section $\mathrm{B}$ is on access to the internet while section $\mathrm{C}$ consist of items on general use of the internet. Section D comprises items on specific use while section E is on the respondents feelings about the internet. The reliability estimate of the items on general and specific use of the internet range from .92 to .98 while that of items on feelings about the internet range from .52 to .67 respectively

For the purpose of this study, the questionnaire was administered to final year students of Federal College of Education, Abeokuta. These are student who are training to become teachers. 200 hundred copies of the questionnaire were randomly distributed to students in the Educational technology class. As students receiving training in Educational technology, they were expected $t$ be aware of the importance and use of the Internet in instruction. Out of the 200 questionnaire only 194 were returned and these were analyzed for discussion. This forms $97 \%$ return rate. 


\section{1. Data Analysis}

Out of these 194 participants, 67 (34.5\%) were males while 127 (65.5\%) were females. Data collected was analyzed using t-test. T-test is a tool used to determine whether there was any significant difference between the means of two random samples.

\section{RESULTS}

$60(89.5 \%)$ of males and 121(95.2) of the female participants claim to be on line while $57(85 \%)$ males and $113(89 \%)$ females were on social network. It is also obvious that Twitter is more popular with the males than females. The results also indicate that getting information for school work, communication, chatting and social networking are the major use to which the participants put the internet. Among the social networks popular among these pre-service teachers, Facebook is identified to be the most popular social network among the participants. This is followed by 2 go.

This is evident in Table 1

Table 1. Participants Use of social network.

\begin{tabular}{|c|c|c|c|c|}
\hline Participation & Male & \% & Female & \% \\
\hline Facebook & 61 & 91 & 104 & 82 \\
\hline 2go & 56 & 83 & 91 & 71.6 \\
\hline Whatsapp & 25 & 37 & 53 & 42 \\
\hline Eskimi & 15 & 22 & 31 & 24.4 \\
\hline Twitter & 30 & 44.7 & 24 & 19 \\
\hline We chat & 3 & 4.4 & 1 & 0.7 \\
\hline
\end{tabular}

In the same vein, while the participants have positive feelings about internet activities like emails, chatting, reading and downloading course related materials which they count as fun and convenient; they have negative feelings about activities like online dating and playing games online. While $97(76.3 \%)$ and 90 (70.8) of the females count email and chatting fun and convenient respectively, $67(53 \%)$ and $86(67.7 \%)$ of them found playing games online and online dating respectively frustrating and waste of time. The same pattern is also evident for males.

\section{Hypotheses Testing}

Hypothesis 1: There is no significant difference in the general use of the internet by male and female participants

General use of the internet has to do with communicating with others, visiting websites, playing games on line, chatting with friends on line, social networking and getting information 
for school work. Here, the mean score of the males stood at 18.9, while that of the females was 17.32, the $t$ calculated was 3.95 with a t critical value of 1.96 . This is presented in Table 2.

Table 2. Gender comparison of general internet usage.

\begin{tabular}{c|c|c|c|c|c|c}
\hline Gender & $\mathrm{n}$ & $\overline{\mathrm{x}}$ & $\mathrm{SD}$ & Df & Tcal & Tcrit \\
\hline Male & 67 & 18.9 & 3.05 & & \\
Female & 127 & 17.32 & 3.70 & & 3.95 & 1.96 \\
\hline
\end{tabular}

$* \mathrm{P}<0.05 ; \mathrm{df}=195 ;$ tcal $=3.95 ;$ tcrit $=1.96$

As evident in Table 2, the value of tcalculated (3.95) is greater than the value of tcritical (1.96) given 195 degree freedom at 0.05 level of significance. This result shows that there is a significant difference in the general internet use by male and female participants. Therefore the null hypothesis was rejected while the alternate hypothesis is accepted that there is a significant difference in the general internet use by male and female participants. This implies that gender of the participants affect their general use of the internet

Hypothesis 2: There is no significant difference in the specific use of the internet by male and female participants

Specific use of the internet involves sending emails, visiting chartrooms, online dating, instant messaging, and accessing public information online like weather and online like banking, listening to music online as well as watching video online. Here, the mean score of the males stood at 30.5, while that of the females was 25.9, the $t$ calculated was 5.05 with a $t$ critical value of 1.96. This is presented in Table 3.

Table 3. Specific use of internet by male and female participants.

\begin{tabular}{c|c|c|c|c|c|c}
\hline Gender & $\mathrm{n}$ & $\overline{\mathrm{x}}$ & $\mathrm{SD}$ & $\mathrm{df}$ & tcal & Tcrit \\
\hline Male & 67 & 30.5 & 5.80 & & & \\
Female & 127 & 25.9 & 6.47 & 195 & 5.05 & 1.96 \\
\hline
\end{tabular}

$* \mathrm{P}<0.05 ; \mathrm{df}=195 ; \mathrm{tcal}=5.05 ;$ tcrit $=1.96$

Table 3 shows that the value of t-calculated (5.05) is greater than the value of tcritical (1.96) given 195 degree freedom at 0.05 level of significance. This result shows that there is a significant difference in the specific internet use by male and female participants therefore the null hypothesis is rejected while the alternate hypothesis is accepted that there is a significant difference in the specific internet use by male and female participants. This implies that gender of the participants affect their specific use of the internet

Hypothesis 3: There is no significant difference in the feelings of male and female participants about the internet 
The feeling of participants about the internet were measure in terms of whether use of the internet for both general and specific purposes was fun, convenient, frustrating or waste of time. With a mean of 30.85 for males and 28.9 for females and t-calculated value of 2.17 , the value of t-calculated (2.17) is greater than the value of tcritical (1.96) given 195 degree freedom at 0.05 level of significance. This is presented in Table 4 .

Table 4. Feelings of male and female to internet use.

\begin{tabular}{c|c|c|c|c|c|c}
\hline Gender & $\mathrm{n}$ & $\overline{\mathrm{x}}$ & $\mathrm{SD}$ & $\mathrm{df}$ & tcal & Tcrit \\
\hline Male & 67 & 30.85 & 5.26 & & & \\
Female & 127 & 28.9 & 7.07 & & 2.17 & 1.96 \\
\hline
\end{tabular}

$* \mathrm{P}<0.05 ; \mathrm{df}=195 ; \mathrm{tcal}=2.17 ;$ tcrit $=1.96$

This result indicates a significant difference in the general feelings of the male and female participants to internet use. Therefore the null hypothesis is rejected while the alternate hypothesis is accepted that there is a significant difference in the general feelings of the male and female participants to internet use. This implies that gender of the participants affect their feelings towards the use of the internet.

\section{CONCLUSION}

The findings of this study indicate that there is a significant difference in the general internet and specific use of the internet by male and female participants in this study, while there is also a significant difference in the general feelings of the male and female participants to internet use, This indicates that gender affects both use and feeling of pre-service teachers about the internet. It therefore implies that gender is a major factor to be considered in use of as well as feeling about the internet.

\section{Recommendation}

In view of the foregoing, it recommended that:

Policies should be put in place to enhance existing ICT skills of all pre-service teachers especially females. Since it is evident that most of the participants depend more on handsets to access the internet an indication of limited access to technology. Therefore, our educational institutions should improve women's access to ICT by providing accessible ICT facilities for the use of student teachers

\section{References}

[1] Anasi S., University of Dar es Salaam Library Journal 8 (1) (2006) 1-15.

[2] Denny-Brown, C. \& Thomas, A. (2013) The Inequality of the "Great Equalizer:" Closing the Internet access gender gap. Available at http://dalberg.com/blog/?p=1555 
[3] Dholakia, R. R., Dholakia, N. \& Kshetri, N.( 2003) Gender and Internet Usage. Available at: http://ritim.cba.uri.edu/wp2003/pdf_format/Wiley-Encycl-Internet-Usage-GenderFinal.pdf

[4] Ferdi, S. (2010). The Top Ten Reasons Why Teachers Use the Internet. Available at: http://paedpsych.jk.uni-

linz.ac.at/paedpsych/NETSCHULE/NETSCHULELITERATUR/Serim97.html http://www.english.illinois.edu/-people-/faculty/debaron/482/482readings/onogender.pdf

[5] Jagboro, K. O. (2003). A study of Internet usage in Nigerian universities: A case study of Obafemi Awolowo University, Ile-Ife, Nigeria. First Monday: Peer Reviewed Journal on the Internet. 8(2). Available at: http://www.firstmonday.dk/issues/issue8_2/Jagboro.com/asia/pk.htm

[6] Jones, S., \& Madden, M. (2002). The Internet goes to college: How students are living in the future with today's technology. Washington, DC: Pew Internet and American Life Project. Available at http://www.pewinternet.org/PPF/r/71/report_display.asp

[7] Korgen, K., Odell, P., \& Schumacher, P. (2001). Internet use among college students: Are there differences by race/ethnicity? Electronic Journal of Sociology. Available at: http://epe.lac-bac.gc.ca/100/201/300/ejofsociology/ 2001/v05n03/content/vol005.003/korgen.html.

[8] Mishra M. K. (2009). Use and importance of the Internet at the University of Maiduguri, Nigeria. First Monday: Peer Reviewed Journal on the Internet 14(3) Available at: http://firstmonday.org/htbin/cgiwrap/bin/ojs/index.php/fm/article/viewArticle/2301/2118

[9] Nai Li a, Gill K., Computers \& Education 48 (2007) 301-317.

[10] Ojokoh B. A., Asaolu M. F.,Africa Journal of Library,Archives and Information Science 15(2) (2005) 149-153.

[11] Omotayo B. O., The International Information \& Library Review 38 (2006) 215-224.

[12] Ruzgar, N. S. (2005) A Research on the Purpose of Internet Usage and Learning via Internet. The Turkish Online Journal of Educational Technology. volume 4, Issue 4, Article 4.

[13] Selwyn N., Marriott N., Marriott P., Higher Education Quarterly 54(2) (2000).

[14] Sherman Richard, C., et.al., Cyber Psychology \& Behavior 3(5) (2000).

[15] Singh Supriya, New Media \& Society 3(4) (2001) 395.

[16] Tadasad P. G., Maheswarapp B. S., Alur S. A., Annals of Library and Information Studies 50(1) (2003) 31-42.

[17] United Nations (2008). Gender: concepts and definitions. Available at: http://www.un.org/ women watch/osagi/conceptsanddefinitions.htm

[18] Usun S., Turkish Online Journal of Distance Education 4(3) (2003).

[19] Viegas J. (2013) 10 Gender Differences Backed Up by Science. Available at: http://news.discovery.com/human/life/science-behind-gender-differences-130528.htm

[20] Tomáš Hes, Anna Poledňáková, International Letters of Social and Humanistic Sciences 2 (2013) 18-31.

[21] Mohsen Mehrara, Masoumeh zirak, International Letters of Social and Humanistic Sciences 2 (2013) 32-38.

[22] Taiwo Adewale Muritala, Ismail O. Fasanya, International Letters of Social and Humanistic Sciences 2 (2013) 39-50.

[23] Borowski A., International Letters of Social and Humanistic Sciences 3 (2013) 46-53.

[24] Borowski A., International Letters of Social and Humanistic Sciences 3 (2013) 69-74.

[25] Donovan A. McFarlane, International Letters of Social and Humanistic Sciences 4 (2013) 35-44. 
[26] Rajesh K. Yadav, Nishant Dabhade, International Letters of Social and Humanistic Sciences 4 (2013) 49-69.

[27] Borowski A., International Letters of Social and Humanistic Sciences 4 (2013) 70-74.

[28] Paul Bukuluki, International Letters of Social and Humanistic Sciences 5 (2013) 27-44.

[29] Mohsen Mehrara, Maysam Musai, International Letters of Social and Humanistic Sciences 5 (2013) 55-62.

[30] Debiprasad Mukherjee, International Letters of Social and Humanistic Sciences 6 (2013) 41-48.

[31] Tomáš Hes, Alena Neradová, Karel Srnec, International Letters of Social and Humanistic Sciences 7 (2013) 55-75.

[32] Kinga Dziwańska, International Letters of Social and Humanistic Sciences 7 (2013) 96-112.

[33] Borowski A., International Letters of Social and Humanistic Sciences 7 (2013) 113-118.

[34] Mohsen Mehrara, Maysam Musai, International Letters of Social and Humanistic Sciences 8 (2013) 1-7.

[35] Jacek Tittenbrun, International Letters of Social and Humanistic Sciences 11 (2013) 10-34.

[36] Mohsen Mehrara, Hamid Abrishami, Mostafa Boroujli, Mahan Amin, International Letters of Social and Humanistic Sciences 11 (2013) 76-83.

[37] Borowski A., International Letters of Social and Humanistic Sciences 11 (2013) 100-105.

[38] Sele Sylvester Ebisin, International Letters of Social and Humanistic Sciences 2 (2014) $1-9$.

[39] Tittenbrun J., International Letters of Social and Humanistic Sciences 2 (2014) 20-40.

[40] Borowski A., International Letters of Social and Humanistic Sciences 2 (2014) 110-121.

[41] Pawa Tersoo, International Letters of Social and Humanistic Sciences 3 (2014) 26-36.

[42] Rabi'u Muhammad Ishaq, International Letters of Social and Humanistic Sciences 3 (2014) 37-44.

[43] Adoga James Ada, International Letters of Social and Humanistic Sciences 3 (2014) 45-52.

[44] Bahram Meihami, Hussein Meihami, International Letters of Social and Humanistic Sciences 3 (2014) 80-91.

[45] Onyike Maggaret Odu, International Letters of Social and Humanistic Sciences 4 (2014) 31-39.

[46] Uloma Charity Oguzor, International Letters of Social and Humanistic Sciences 4 (2014) 97-104.

[47] Okezie A. Ihugba, Alex Odii, A. C. Njoku, International Letters of Social and Humanistic Sciences 5 (2014) 21-34.

[48] Okezie A. Ihugba, Bankoli Bankong, N. C. Ebomuche, International Letters of Social and Humanistic Sciences 5 (2014) 92-113. 